tion of the elements analogous to that of radioactive bodies. On this view the heavier elements are split up into lighter and even into new and simpler elements which he has called "protoelements." The evolution of the stars is accompanied by a simultaneous evolution of the simple elements of Nature.

The great chemist, Ramsay, who was a pioneer in many directions, gave the greatest attention to these new ideas and to the numerous observations which appeared to support them. The classification of the stars in accordance with the foregoing tests has been fully confirmed by optical measurements of their absolute temperatures.

To sum up, in his latest researches, as well as in the first, Sir Norman Lockyer has exhibited an aptitude for experiment, a creative faculty, a penetration, and a breadth of view which are truly remarkable; and the results obtained on the sole basis of experiment are of the first importance. $\mathrm{He}$ is one of the great men of science of England and one of the greatest astronomers of all time. Finally, let us hope that, bearing the weight of years in comfort, he may continue his services to science and his association with this journal, and witness for himself the increasing success of his ideas and his methods.

\section{H. DESLANDREs.}

(Vice-President of the Academy of Sciences of Paris, Director of the Astrophysical Observatory of Meudon.)

\title{
RETROSPECT AND PROSPECT.
}

By Sir Archibald Geikie, O.M., K.C.B., F.R.S.

FIFTY years have passed since the publication of the first number of Nature on November 4, I869. To start successfully a weekly journal entirely devoted to chronicling the onward march of science was an experiment that could not but involve some financial risk, and certainly required no small editorial ability. To maintain such a journal for half a century on a high level of excellence, and to gain for it a place admittedly of importance in the periodical literature of our time, is a feat of which Editor and publishers have good reason to be proud. The weekly contributions of this journal to current scientific literature now amount altogether to more than a hundred volumes, which contain a contemporary record of the progress made by every department of natural knowledge, often contributed by the men to whom the progress was due. It may be appropriate, as we take note of this achievement, to cast an eye back upon the condition of science among us fifty years ago, to survey our present position, and to look forward into the vista that is opening out for the future.

In taking such a retrospect one of the most conspicuous and satisfactory features to attract attention is the remarkable increase and steady growth of fresh centres of higher education all over Britain, where not only is the time-honoured literary side cherished, but ample room and full equipment are found for the theoretical and practical teaching of science. These centres, beginning perhaps as modest colleges, have attracted a constantly increasing number of students, and each of them has become a nursery in which the men of science of the future are being bred. A convincing proof of their vitality is furnished by their successful claim for recognition as universities. They have already added half a dozen new universities to our educational strength, and this year one of the youngest yet most important of NO. 26 IO, VOL. IO 4 ] them, the Imperial College of Science and Technology, is now in turn demanding the status and powers of a university. There has never been a time in our history when the opportunities for obtaining a thorough scientific training have been thrown open so widely and attractively, and when advantage has been taken of them in so large a measure.

That one of the great duties of a nation is to promote the cultivation of science by appropriating funds not only in aid of education in theory and practice, but also in support of research and experiment, never began to be realised until within living memory. British science has attained its greatness without State aid. There are, indeed, a few directions in which public money has been disbursed for scientific objects, such, for instance, as Greenwich Observatory, the British Museum, and the various geographical expeditions and geological surveys. But not until the middle of last century did it dawn upon the attention of the Ministry of the day, awakened possibly by the portents of the coming Great Exhibition of $185 \mathrm{I}$, that men of science are not as a rule wealthy, that they must often be involved in considerable expense in carrying on their researches, that they cannot always look to the universities, colleges, or learned societies for financial support, and therefore that it might be of public advantage to come to their help from the public purse. Accordingly, in November, I849, Lord John Russell, then Prime Minister, sent a confidential communication on the subject to the president of the Royal Society (Earl of Rosse), who remitted to a committee to report how a financial grant, if made by Government, could best be employed.

After deliberate Governmental consideration for the space of nearly a year it was decided at the beginning of 185 to make an annual grant of one thousand pounds to be administered by the Royal 
Society, chiefly in aid of private individual scientific investigation. At the end of four years the Treasury declined to continue the grant of this sum (trifling as it was, compared with the revenue of the country), on the ground that the fund from which it was taken would no longer admit of "an annual grant to the Royal Society." The council replied with spirit that it was not a grant to the Royal Society, but "a contribution on the part of the nation towards the promotion of science generally in the United Kingdom," the council being only trustees for the due administration of the fund. The grant was then placed on the Parliamentary Estimates, and the Ioool. continued to be paid annually for nearly twenty years. In 1877 the vote was increased to $4000 l$, , but the council had still some difficulty in preventing the grant from being regarded as one to the Royal Society, which was in no way benefited by it, but, on the contrary, had an onerous and difficult task in looking after its proper administration. In 1894 application was made for an increase in the amount of the grant, but without success.

Meanwhile the German Government, looking keenly to the future and thoroughly impressed with the importance of stimulating the cultivation of science, was spending large sums to equip laboratories and otherwise further education in science, and to stimulate discovery and invention. The example of that country was often cited here, and contrasted with the unsympathetic attitude and stingy support of our authorities, much to the surprise and annoyance of the permanent officials of the Treasury, who rather seemed to think that their grants to science were remarkably liberal. I remember an occasion when I had to go to the Treasury about a matter connected with the Geological Survey. The official on whom I called was one of the heads of the Department, with whom I had long been on terms of friendly intimacy. He began the interview by saying that he would be glad to hear me, but begged that the example of Germany might not be mentioned.

Happily these times of indifference belong to the past. Twenty years ago an appeal was made to Government for the creation of a National Physical Laboratory for the purpose of standardising and verifying instruments, testing materials, and for the determination of physical constants. After some effort and with the persistent support of Lord Rayleigh, the appeal was eventually successful. The institution began on a modest scale with a staff of only twenty-six, no more than two departments, and a small grant annually voted by Parliament. But under the able supervision of Sir Richard Glazebrook it rapidly increased the scope of its work, the extent of its buildings, and the size of its staff, until the burden of responsibility for its administration was becoming too heavy for the Royal Society. In April of last year it was transferred to the newly established Department of Scientific and Industrial Research, the number of its departments of investigation having. now grown to seven, and that of the staff to more than 6oo. In this enlarged sphere of public utility NO. 26 ro, VOL. IO4] it will no doubt achieve still greater success, while at the same time research in all directions and its practical applications will be greatly quickened. The day of parsimony in regard to the prosecution of scientific inquiry and its applications is now gone beyond the power of any Government to revive.

Obviously it is not zeal for the advance of pure science that has led to the augmented general interest in research. The appreciation of the practical value of many discoveries in relation to the daily life of mankind has naturally been the main stimulus. The philosophers might have experimented until doomsday upon æther and its undulations without awaking more than a languid interest in their work, or receiving any pecuniary help in their expenses; but when they showed that by means of these undulations messages could be flashed across the ocean without any wires, the public imagination was at once excited, and millions of money were ready for investment in any company that would undertake to fit up the necessary apparatus for sending such messages. In like manner, there might have been but a feeble appreciation of the phenomena of radioactivity, but when it was shown that by means of Röntgen rays the surgeon could see the bones inside a human body and detect there the existence and exact place of any bullet or other dense substance, a wide interest in the discovery was awakened, and little difficulty was found in supplying every hospital with the requisite apparatus.

The War has brought the economic value of science before the world on a colossal scale of demonstration. While scientific inventions have enormously algmented the offensive powers of the belligerents, it is pleasing to know that the applications of science have not been all on the destructive side, but that at the same time the greatest stimulus in the history of mankind has been given to medicine and surgery, and that each of these great divisions of the healing art has made notable advances and gained fresh powers for dealing with diseases and wounds.

Exactly ten years had elapsed after the publication of Darwin's "Origin of Species" when the first number of NATURE was issued. The doctrine of Evolution had long been before the world. Laplace had introduced it into the history of the solar system; Lamarck, after Buffon, had proposed an ingenious ætiology in the history of organised life upon the earth; while towards the middle of last century came the cruder efforts of the author of the "Vestiges of the Natural History of Creation," which so perturbed the minds of his generation. But it was not until after the appearance of Darwin's book, and in consequence of that book, that Evolution came slowly to be regarded as the great law of the whole cosmos. If we consider broadly the relation of the community to scientific progress during the last fifty years, its most outstanding feature will probably be recognised in the general acceptance of this great generalisation.

The views of Darwin made their way with 
more speed on the Continent than in his own country. Probably not many survivors are left to recall the astonishment and indignation with which some of the older geologists of the day read his two chapters "On the Imperfection of the Geological Record" and "On the Geological Succession of Organic Beings." To the younger men, on the other hand, these chapters were a luminous revelation. I shall never forget their influence on myself. They gave me a new key to unlock the history recorded in the rocky crust of the globe. They linked together Stratigraphy and Palæontology in the most masterly way, making each of them explanatory of the other, and confirming the doctrine of Evolution more clearly than ever.

The bearing of the "Origin of Species" on social questions was more promptly recognised abroad than at home. Thus, in the first number of Nature, it was stated that when the Austrian Reichsrath, after the disastrous war with Prussia, assembled in December, I866, to deliberate on the best means of re-consolidating the prostrate empire, a distinguished member of the Upper Chamber, Prof. Rokitansky, began a great speech with this sentence: "The question we have first to consider is, "Is Charles Darwin right or no? ", Such phrases as "the struggle for existence" and "the survival of the fittest" have not only become household words, but they have been brought into the domain of social relations and of the physical improvement of mankind. Foremost among those who have insisted on the vital importance of these subjects to human society was Darwin's cousin, Sir Francis Galton, to whose writings and persistent advocacy the new study of Eugenics owes its existence.

In one important branch of research Britain has always taken a foremost place. Geographical exploration, where it can be undertaken by the Navy, has long been a favourite task with our Admiralty. The earlier expeditions were mainly intended for geographical discovery. Those of the last fifty years have been in increasing measure devoted to scientific observations in magnetism, meteorology, oceanography, and natural history. A new type of equipment has thus arisen, in which each vessel becomes a kind of floating workshop of laboratories, microscope rooms, photographic chambers, and all the other requirements of physical and biological science. It was the naturalists who asked for State assistance in the exploration of the ocean, its temperature, currents, depths, and living things. In I 868 they succeeded in obtaining from the Admiralty the services of the Lightning, and two years later of the Porcupine. These tentative missions brought to light so much fresh information and raised so many new problems that, in response to a loud appeal from the scientific world, the Challenger was prepared on a more complete and elaborated scale, fitted with every kind of appliance, and furnished with a company of skilled investigators, under the leading of a distinguished NO. 26 IO, VOL. [04] naturalist. For the first time in the history of exploration the globe was circumnavigated during four years $(1872-76)$, not for the discovery of new lands, but for an investigation of the oceans from their surface waters to their utmost depths. Splendid in its conception and admirable in its achievement, this great expedition laid a solid foundation for the new department of science which has now been named Oceanography. And the fifty quarto volumes in which its labours and results are recorded form a noble monument of successful research.

Since that time the problems of the Antarctic regions have been attacked by several expeditions. The two brave adventures of Capt. Scott and his associates in IgOI and Igro, amply supported by the Admiralty, were meant not merely for the increase of geographical knowledge, but were fitted out with all the needful appliances for observations of the magnetism, meteorology, geology, and zoology of the area around the South Pole. They have added much to our knowledge of Nature in that region of the globe.

If, now, we cast our eyes towards the future, the prospect for British science is eminently encouraging. The opportunities for research and experiment were never before so ample, the cooperation of the State never so cordial, the ranks of the investigators never so full, and the joy and enthusiasm for investigation never more ardent. For years to come this prosperity ought to continue and increase. But unquestionably in the distance a cloud may be discerned, which has long been in sight, but is now much nearer. Our present great source of power is coal, but at a not very remote date our coal-fields will be exhausted. If before that time some other source is not discovered, our position as a great manufacturing country will be seriously affected. Hopes have been raised on the possibility of finding large supplies of mineral oil in our islands. It is well known that in one or two places oil has long been coming to the surface in small quantities. It is possible that these indications may point to larger supplies below. But we are still so ignorant of the distribution of the oil within the earth that no confident prognostications are warranted. Much misunderstanding still exists on this subject. There can be now no doubt that the oil found so abundantly in some regions has no connection with coal-fields or with any deposits of organic origin, but comes from a depth probably below all the stratified part of the terrestrial crust. The most probable explanation of its origin is that it results from the decomposition of carbides forming part of the original constitution of the globe. These carbides, or compounds of carbon with some metal, such as iron, are decomposable by water and then give rise to the production of hydrocarbons, such as mineral oil and marsh gas. If water descending from the surface through the upper crust should reach those deeper-seated compounds, this decomposition would take place, and the pressure of the 
generated gas might force the oil up the fissured crust to the surface. Only where it makes its appearance do we know for certain that there must be some oil below, but whether in quantity sufficient even to repay the cost of boring for it cannot be predicted.

But before our coal supplies are worked out, and whether or not we discover subterranean supplies of oil, we may surely hope that some of the sources of power which are now unused will be harnessed to the service of man. To the waterfalls, tides, and winds, which have long been considered, Sir Charles Parsons in 1904 suggested another possible source of power in the internal heat of the globe, and in his recent presidential address to the British Association he has returned to the subject. His proposal is to sink a bore-hole 12 miles deep, which would cost five million pounds and require about eighty-five years for its completion. With the use of a fresh source of power and an extended development of electricity, we should doubtless be able to hold our own in the competition of the nations.

It may be allowed to me to end this article on a more personal note. To the foresight, energy, and constant attention bestowed on NATURE by its founder, Sir Norman Lockyer, the world of science has been indebted during half a century for the possession of a journal which with persistent force has sustained the cause of science in this country, has been an invaluable medium for recording the progress of research and discovery, and has played a most useful part as a medium for the discussion of questions of general interest and for public intercommunication between the cultivators of science, to whom it has become indispensable. I contributed to its first number, and have often sent communications since then, and now I am proud to be asked to write a preface to this jubilee issue and to wish continued life and prosperity to my old and valued friend, the founder of the journal.

\section{THE FOUNDATION OF BIOLOGICAL SCIENCES.}

\section{By Sir E. Ray Lankester, K.C.B., F.R.S.}

WHEN the first number of NATURE was pub$V$ lished in November, 1869, the word "biology" had not the currency now given to it. The word had been adopted by Whewell, and was used by Treviranus and philosophical writers of the early half of last century. What is now called hypnotism was termed "electro-biology," but the extent of the great field of exploration signified by "biology" was little understood. The great event in the history of biological science occurred ten years before the appearance of the first issue of NATURE, namely, in 1859, when Darwin published his book "On the Origin of Species by Means of Natural Selection or the Preservation of Favoured Races in the Struggle for Life."

The new conception of organic phenomena brought about by Darwin's work took deep root in the ten years from I859 to 1869 , and the main lines of study necessitated by it had been boldly laid by the pioneers, chief of whom were Huxley and Hooker. One main line of work set going, and ever since continued, was the production of further evidence of the kind brought forward by Darwin and Wallace. The period was one of intense activity and movement. The Darwinian theory spread in every direction, and new evidence in its favour was accumulated by naturalists, collectors, and explorers. By a remarkable coincidence, the year 1859 was marked not alone by the publication of the "Origin of Species," butowing to the work of Joseph Prestwich and a small group of English geologists-it is definitely distinguished as the date when the occurrence of flint implements in the gravels of the Somme was recognised as proving (as had been maintained since 1847 by $M$. Boucher de Perthes and NO. $26 \mathrm{IO}$, VOL. IO4] denied by the French savants) the existence of man as a contemporary of the mammoth and the woolly rhinoceros.

When this journal started its career we had already Darwin's additional volume on the "Variation of Animals and Plants under Domestication," which was followed in 1871 by the "Descent of Man." Practically the whole scientific world (and much of the thinking world outside it) had been convinced of the truth of the doctrine of organic evolution and also of the vast antiquity of man. The evolution of man from animal ancestry, with all its consequences as to the development of the human mind, became an inevitable inference.

\section{Elementary Biology.}

By the year 1869 the triumph of the Darwinian theory was assured. In that year Huxley began his course of lectures and laboratory work on elementary biology. The class numbered about a hundred, and Huxley's three assistants were (Sir) Michael Foster, Rutherford (then professor at King's College, London, afterwards professor at Edinburgh), and myself. This course of lectures to teachers, which was given also in the following year, largely emphasised the unity of animals and plants, and it aroused great enthusiasm. Each lecture by Huxley was followed by demonstrations by his assistants in the laboratory, which lasted all day. This became the model for the courses in biology in all Englishspeaking countries, and formed the basis of the examinations in the University of London.

Huxley by no means sought to put forward zoology at the expense of physiology and botany. In the new laboratories at South Kensington the 